\title{
RELATIONSHIP FACTORS IN TOURISM SUPPLY CHAIN MANAGEMENT IN SLOVENIA AND CROATIA
}

\author{
Sonja Mlaker Kač \\ Edna Mrnjavac \\ Nataša Slavić
}

https://doi.org/10.20867/tosee.05.25

\begin{abstract}
Purpose - The aim of the article is to examine what are the relationships factors that are influencing tourism supply chains and relationships among partners in tourism supply chains.

Our theoretical basis for research is relationship commitment - trust theory (Morgan \& Hunt, 1994).

"A tourism product is often configured from a variety of service providers (accommodation, transport and attraction providers) that form tourism supply chain. The fragmented nature of tourism products/services implies that individual suppliers often rely on cooperation with one another" (Song 2012, 25). And that is why we think it is worth examining the factors that influence the relationships in tourism supply chains. So, the article combines three different research areas: supply chains, marketing relationship theory and tourism sector.

Methodology - Two touristic very well developed and interesting countries were included in research: Slovenia and Croatia. The research was conducted with an online and live questioner and had 26 statements about different relational factors.

Findings - The results show several correlations and futher on also influences of different factors on collaborative bahavour between partners in supply chains. The results show that relationship commitment in tourism supply chain, trust in tourism supply chain and communication have a semi strong positive influence on collaboration between partners in tourism supply chain. The results also show that relationship commitment in tourism supply chain, communication in tourism supply chain, shared values in tourism supply chain have a semi strong positive influence on trust between partners in tourism supply chain. The results show that communication in tourism supply chain and shared values have a semi strong positive influence on relationship commitment between partners in tourism supply chain.

Contribution - We can sum up that it is important for the tourism sector to be aware of the meaning of trust, communication, shared values and relationship commitment on the collaborative behaviour between stakeholders involved in their partnership network. We can conclude from our research results that successful and long-term oriented supply chain the tourism sector in Croatia and Slovenia cannot exist in the collaborative sense of working together without relationship commitment, trust, shared values and good communication between partners in tourism supply chains.
\end{abstract}

Keywords Tourism supply chain, collaboration, trust, shared values, communication, relationship commitment 
ToSEE - Tourism in Southern and Eastern Europe, Vol. 5, pp. 475-487, 2019

S. Mlaker Kač, E. Mrnjavac, N. Slavić: RELATIONSHIP FACTORS IN TOURISM SUPPLY CHAIN ...

\section{INTRODUCTION}

The article combines three different research areas: supply chains, marketing relationship theory and tourism sector. Two touristic very well developed and interesting countries were included in research: Slovenia and Croatia.

According to relationship commitment- trust theory (Morgan and Hunt 1994), trust, shared values, relationship commitment and communication are important factors when achieving collaborative relationships. And according to Song (2012) all these factors are also important for successful tourism supply chain.

For understanding and researching relationships in tourism supply chains it is important to understand and point out some specifics of tourism (Song 2012,6):

- tourism is a coordination intensive industry where different products/services are bundled together to form a final tourism product,

- tourism as a product is perishable,

- tourists need to travel to the destinations where tourism products are produced to consume these products,

- tourism industry is very information intensive,

- $\quad$ tourism products are very complex in nature and have huge dynamics.

Because of all before listed reasons it is very important to have good relationship with partners included in tourism supply chain.

The research has been conducted in Croatia and Slovenia, both very well developed tourist destinations. Croatia is one of the most significant tourist destination on the Mediterranean and has a long tradition and much space for further development (Baldigara and Mamla 2012). According to World Travel and Tourism Council (2018a) Croatia has a constantly growing tourism sector in GDP sense since 2012, and predictions for future are also forecasting the positive directions (11\% of the whole economy GDP in 2018). Tourism in Croatia has both huge direct and indirect (10\% of the whole economy GDP in 2018) effect and the additional induced (4\% of the whole economy GDP in 2018) effect (World Travel and Tourism Council 2018a). Croatia is mostly known as leisure destination (93.3\% leisure spending and 6.7 for business spending in 2017) and it mostly attracts foreign visitors (84.7\% foreign visitors, $15.3 \%$ domestic in 2017) (World Travel and Tourism Council 2018a). Slovenia is much smaller tourist destination developing rapidly in last years and the interest for research in tourism sector is growing as well (Rangus and Brumen 2016). According to World Travel and Tourism Council (2018b) Slovenia is stable in GDP sense for last decade (3.4\% of the whole economy GDP in 2018). Tourism in Slovenia has bigger indirect effect (around 7 $\%$ of the whole economy GDP in 2018) and a small additional induced effect ( $2 \%$ of the whole economy GDP in 2018) (World Travel and Tourism Council 2018b). Slovenia is mostly known as leisure destination like Croatia thou the percentage of business spending is higher in Slovenia than in Croatia (85.2 \% leisure spending and 14.8 for business spending in 2017) and it mostly attracts foreign visitors, but the percentage is much smaller than in case of Croatia (66.2\% foreign visitors, $33.8 \%$ domestic in 2017) (World Travel and Tourism Council 2018b). 
ToSEE - Tourism in Southern and Eastern Europe, Vol. 5, pp. 475-487, 2019

S. Mlaker Kač, E. Mrnjavac, N. Slavić: RELATIONSHIP FACTORS IN TOURISM SUPPLY CHAIN ...

\section{THEORETICAL BACKGROUND}

Zhang, Song and Huang (2009) define the Tourism Supply Chain (TSC) as "a network of tourism organizations involved in a series of diverse activities, ranging from providing an entire spectrum of components of tourism products/services, such as flights, accommodation at the tourism reception desk, and ending with the sale of tourism products in the tourism region. This network includes a wide range of subjects, both from the private and the public sector that are involved in the creation, sale, and promotion of tourism products" and the definition is related to the most common and widely used definition of supply chain by Waters (2007) and Christopher (2011).

"Tourism supply chain can be shortest defined as "a set of approaches utilised to efficiently manage the operations of the tourism supply chain within a specific tourism destination to meet tourist needs from the targeted source markets and accomplish the business objectives of different enterprises within the tourism supply chain" (Song 2012, $1)$.

Kaukal, Hopken and Werthner $(2000,1105)$ note that a typical tourism value chain consists of four components: tourism supplier, tour operator, travel agent and customer and they are in single link chain. And the links between partners in supply chains are focused around four main points in the tourism supply chain: (1) accommodation, (2) transport, (3) ground handlers, excursions and activities, (4) food and crafts (Tapper and Font 2004, 4-5).

Tourism supply chain can be best understood and presented in the following figure (Figure 1). It is a linkage between all partners in hospitality and travel industry. And it has to understood and researched from the broadest perspective possible.

Figure 1: Tourism supply chain

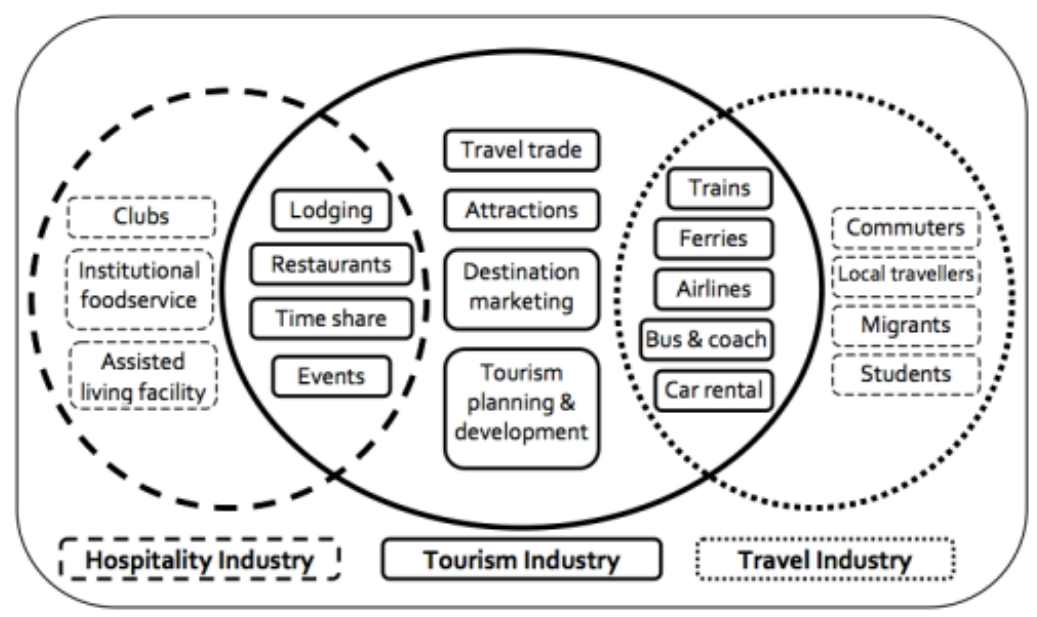

Source: Piboonrungroj, 2009 
ToSEE - Tourism in Southern and Eastern Europe, Vol. 5, pp. 475-487, 2019

S. Mlaker Kač, E. Mrnjavac, N. Slavić: RELATIONSHIP FACTORS IN TOURISM SUPPLY CHAIN ...

The figure 1 shows as a network of tourism organisations supplying different components of tourism products/services such as flights and accommodation for the distribution and marketing of the final tourism products. Tourism supply chain involves a many different participants from private and public sectors (Song 2012,6).

Relationship in a supply chain can be categorised into two groups according to their direction: (1) vertical (which exist among heterogeneous players who do not have overlap capability) and (2) horizontal relationships (which concern homogeneous players on the same level of the supply chain who usually have overlapping capabilities) (Song $2012,9)$. We will take both into consideration in our research.

\subsection{Trust in supply chains}

Even though trust is a multidimensional concept (Svensson 2005) we think the best way to measure and research it is from the sociological point of view. And in this sense it is understood "a willingness to rely on an exchange partner in whom one has confidence" (Mooreman, Zaltman and Deshpande 1992). Several authors (Zhang, Song and Huang 2008 and Song 2008) argue that it is also crucial for cooperation and sustainability of the tourism supply chain. It includes two components: first the basic level of trust to start cooperation with someone and then establishment of the long term trust that leads toward long term collaborative behaviour between partners in supply chains.

Two of the most important and challenging things in tourism supply chains are achieving trusting relationship among tourism supply chain partners and establishment of forecasting support systems to facilitate the forecasting process and information sharing amongst the partners within tourism supply chain (Song 2012, 29). These are crucial steps towards successful tourism supply chain.

\subsection{Relationship commitment in supply chains}

Since tourism sector is service oriented and therefore inseparably connected to working with other partners in supply chain, it is also very important for companies that are included in the supply chain to be committed to other companies they are working with. We speak about so called relationship commitment that can be the best defined from marketing perspective. We speak about phenomena where an exchange partner believes "that an on-going relationship with another is as important as to warrant maximum efforts at maintaining it" (Morgan and Hunt, 1994). Tapper and Font (2004) especially emphasize the importance of being committed to several different stakeholders within tourism supply chains (commitment can be based on vertical relationships like commitment between travel providers and travel agencies and on horizontal relationships, such as relationships between different accommodation providers or different transport services). 
ToSEE - Tourism in Southern and Eastern Europe, Vol. 5, pp. 475-487, 2019

S. Mlaker Kač, E. Mrnjavac, N. Slavić: RELATIONSHIP FACTORS IN TOURISM SUPPLY CHAIN ...

\subsection{Collaboration between partners in supply chains}

The key to coordinate the decisions between partners in a tourism supply chain is "to ensure that the objectives of individual tourism supply chain members are aligned with the overall tourism supply chain objective" (Song 2012, 51), which means that they are all together trying to maximise the value and profit of the tourism supply chain on such way it has a positive effect on all partners in supply chain and on tourism supply chain as a whole (Song 2012, 51).

Zhang, Song and Huang (2008, 29-30) discuss the tourism supply chain from coordination perspective and emphasize its importance to successful relationships between partners in tourism supply chains. They point out the importance of integration, which means that partners in the tourism supply chain move to a higher level of working together, in most cases we describe this as collaborative behaviour between partners in tourism supply chain.

Collaboration in tourism context has been research only for last few decades and one of the first authors Gray (1989) described it from tourism point of view as a process of joint decision making among different stakeholders to resolve planning problems of the destination or to manage issues related to the planning and development of the one destination.

Collaboration can be defined (Waters, 2007) as a form of a modern relationship formation used in inter-organizational alliances. Since supply chains are mostly structured as inter-organizational alliances this can be claimed also for tourism supply chains.

The basis for supply chain collaboration establishment can be found in shared objectives, sense of urgency, commitment and belonging, open communication, mutual trust and respect, complementary skills and proper management knowledge (Pollard, 2005). Collaboration between different partners is mostly formed to solve problems, develop new understandings and design new products (Denis, 1999). In our sense this means solving problems that occur in tourism supply chain and planning and designing new tourism products. Collaboration should be also understood as integration and a strategic action as a response to competition from rivals (Song 2012, 70).

\subsection{Communication between partners in supply chains}

Tourism supply chain coordination and collaboration is a pattern of communication and decision making among business connected to tasks performance to achieve mutual supply chain goals (Song 2012, 46).

Collaborative forecasting requires information sharing during this forecasting system (Song 2012, 39) and this is additional reason why communication in tourism supply chain is so important. 
ToSEE - Tourism in Southern and Eastern Europe, Vol. 5, pp. 475-487, 2019

S. Mlaker Kač, E. Mrnjavac, N. Slavić: RELATIONSHIP FACTORS IN TOURISM SUPPLY CHAIN ...

Communication is about exchange of information about concepts, suggestions and attitudes to achieve a specific goal. I can be provided by individuals or organisations (Wang, 2009). It is important to have good internal and external communication, because this also enables supply chain integration (Waters, 2007).

\subsection{Shared values between partners in supply chains}

Shared values are important when establishing trust and integrating between different partners in potential partnerships and later in supply chains (Humphrey, 1998) and this is why they are very important in tourism supply chain as well. Shared values have been very well defined by Morgan and Hunt (1994). They explain it as "the extent to which partners have common beliefs about what behaviours, goals and policies are important or unimportant, appropriate or inappropriate, right or wrong" (Morgan and Hunt, 1994, 26).

\section{METHODOLOGICAL FRAMEWORK}

The research was conducted in 2017 and 2018 with an online and paper questionnaire. We included all different stakeholders of tourism supply chains from Croatia and Slovenia in the research. 162 people that are working actively with partners in tourism and tourism supply chain were included in the research. The research results can only be generalised for Slovene and Croatian environment.

Tourism sector in Slovenia in 2017 had around 56 thousand employees, which represents $6.5 \%$ of all workforce (STO 2018, 3). Tourism sector in Croatia in 2018 had around 140 thousand employees directly connected to tourism sector, which is $10 \%$ of all employments and $3 \%$ more than a year before (World travel\& tourism council 2019). Hotels and restaurants employ in 201792 thousand people, which represents $6.8 \%$ of the total workforce (Ministry of Tourism Republic of Croatia 2018, 41).

26 statements related to the studied and for research important concepts: trust (Morgan and Hunt, 1994, Deepen 2007, Svensson 2005, Chen, Yen, Rajkumar and Tomochko 2011 and Castaldo 2007), relationship commitment (Morgan and Hunt 1994, Deepen 2007, Chen, Yen, Rajkumar and Tomochko 2011, Saab 2007), collaboration (Morgan and Hunt 1994, Deepen 2007, Svensson 2005, Saab 2007, Cao and Zhang 2013), communication (Anderson and Narus 1984, Anderson and Weitz 1992, Morgan in Hunt 1994, Deepen 2007) and shared values (Anderson and Narus 1984, Anderson and Weitz 1992, Morgan and Hunt 1994, Deepen 2007 and Chen, Yen, Rajkumar and Tomochko 2011) were included in the questionnaire. We used a 5 point Likert scale, where 1 represents total disagreement with statement and 5 means absolute agreement with each statement. Additional questions about demographical data were also included in the research.

We measured all factors with following statements:

- Partners which we cooperate with stick to the promise they give to our organization.

- When a partner with whom we cooperate has a problem that affects us, partner informs us about that. 
ToSEE - Tourism in Southern and Eastern Europe, Vol. 5, pp. 475-487, 2019

S. Mlaker Kač, E. Mrnjavac, N. Slavić: RELATIONSHIP FACTORS IN TOURISM SUPPLY CHAIN ...

- Our partners are trustworthy.

- Our success is also important for our partners.

- Our partners perform tasks correctly, even though we cannot control them directly.

- In addition to their own business, our partners also take into account our benefits.

- When criticism of our partners arises, we give priority to our experience with partners before criticism of others.

- We would feel sorry if we should stop working with partners for any reason.

- We try to maintain good relationships with partners.

- We do not feel good if criticism about our partners occurs.

- Our approaches to business or organization are similar to the approaches in the business or organization of our partners.

- Our goals and goals of our supply chain partners are similar.

- When problems in cooperation with partners arise, we try to find the most suitable solutions together with partners.

- If partners in our supply chain enforces their idea, they do it so that we are still willing to work with them.

- The partners we work with are mutually respected.

- We are pleased with the partners we work with.

- We are discussing potential business problems with the partners we work with.

- To achieve our business goals, we need a lot of meetings and conversations with the partners we work with.

- Partners with whom we cooperate are not burdened with irrelevant information.

- The exchange of information between us and our partners flow without delay.

- Exchanged information between partners are reliable.

- Partners who we cooperate with understand the importance of good mutual collaboration.

- The behaviour of partners with whom we cooperate contributes to good mutual cooperation.

- Mutual cooperation is clearly defined.

- Partners strive to achieve good mutual cooperation.

- Organizational values between the partners we work with are similar to ours.

We conducted the statistical analysis with SPSS: first some basics statistical analysis were conducted, furthermore the Pearson's correlation coefficient test, Factor analysis and Multiple Regression analysis were used. From theoretical background we can presume that trust, relationship commitment, communication and shared values in tourism supply chains directly and indirectly influence collaborative behaviour between partners in the tourism supply chain, and our aim of the research is to examine the strength and director of influence of these factors.

So, our research question is: how and to what extend do the relational factors (such as trust, relationship commitment, communication and shared values) influence collaboration in the tourism supply chain. 
ToSEE - Tourism in Southern and Eastern Europe, Vol. 5, pp. 475-487, 2019

S. Mlaker Kač, E. Mrnjavac, N. Slavić: RELATIONSHIP FACTORS IN TOURISM SUPPLY CHAIN ...

\section{RESEARCH RESULTS}

All 26 statements were transformed into 5 different factors: trust in tourism supply chains, relationship commitment in tourism supply chains, collaboration in tourism supply chains, communication and tourism supply chains and shared values between partners in tourism supply chains.

Table 1 shows means and standard deviation of all factors included in our research. The highest average and therefore importance is scored by shared values in tourism supply chains (4.37). Relationship commitment is marked in average with 4.30, collaboration in tourism supply chains 4.11 , trust in tourism supply chain 4.02 and communication in tourism supply chain 3.99 .

Table 1: Mean and standard deviation of measured factors

\begin{tabular}{|l|c|c|c|}
\hline & Mean & Standard deviation & N \\
\hline Trust in TSC & 4.02 & 0.573 & 162 \\
\hline Relationship commitment in TSC & 4.30 & 0.592 & 162 \\
\hline Collaboration in TSC & 4.11 & 0.519 & 161 \\
\hline Communication in TSC & 3.99 & 0.608 & 161 \\
\hline Shared values in TSC & 4.37 & 0.506 & 161 \\
\hline
\end{tabular}

Table 2 presents Pearson's correlation coefficient analysis between all factors.

Table 2: Correlations between relationships factors included into research

\begin{tabular}{|l|c|c|c|c|c|}
\hline & Trust & $\begin{array}{c}\text { Relationship } \\
\text { Commitment }\end{array}$ & Collaboration & Communication & $\begin{array}{c}\text { Shared } \\
\text { Values }\end{array}$ \\
\hline Trust & 1 & $0.453^{* *}$ & $0.616^{* *}$ & $0.541^{* *}$ & $0.603^{* *}$ \\
\hline $\begin{array}{l}\text { Relationship } \\
\text { Commitment }\end{array}$ & & 1 & $0.493^{* *}$ & $0.494^{* *}$ & $0.542^{* *}$ \\
\hline Collaboration & & & 1 & $0,615^{* *}$ & $0,636^{* *}$ \\
\hline Communication & & & & 1 & $0,589^{* *}$ \\
\hline Shared Values & & \multicolumn{4}{|l}{} \\
\hline
\end{tabular}

$* * \mathrm{p} \leq 0.01$

Table 2 shows very strong correlations between collaboration and trust (0.616) and shared values and trust (0.603). There are also strong correlations between communication and trust $(0.541)$ and between relationship commitment and trust (0.453). Table 2 also shows strong correlation between relationship commitment and shared values (0.542), between relationship commitment and communication (0.494) and between relationship commitment and collaboration (0.493). The same table shows correlation between collaboration and communication (0.615) and collaboration and shared values (0.636). There is also correlation between communication and shared values (0.589). 
ToSEE - Tourism in Southern and Eastern Europe, Vol. 5, pp. 475-487, 2019 S. Mlaker Kač, E. Mrnjavac, N. Slavić: RELATIONSHIP FACTORS IN TOURISM SUPPLY CHAIN ...

Based on current Pearson's correlation coefficient results (shown in Table 2), we have also performed a linear regression analysis, where the influence of independent variables towards dependent variables has been analysed.

Table 3 shows the values of regression analysis among the following pairs of variables: (1) relationship commitment in tourism supply chain (as the independent factor) collaboration in tourism supply chain (as the dependent factor), (2) trust in tourism supply chain (as the independent factor) - collaboration in tourism supply chain (as the dependent factor), (3) communication in tourism supply chain (as the independent factor) -collaboration in tourism supply chain (as the dependent factor), (4) shared values in tourism supply chain (as the independent factor) - collaboration in tourism supply chain (as the dependent factor), (5) relationship commitment in tourism supply chain (as the independent factor) -trust in tourism supply chain (as the dependent factor), (6) communication in tourism supply chain (as the independent factor) -trust in tourism supply chain (as the dependent factor), (7) shared values in tourism supply chain (as the independent factor) -trust in tourism supply chain (as the dependent factor), (8) communication in tourism supply chain (as the independent factor) - relationship commitment in tourism supply chain (as the dependent factor), (9) shared values in tourism supply chain (as the independent factor) - relationship commitment in tourism supply chain (as the dependent factor).

Table 3: Regression analysis between relationship factors

\begin{tabular}{|l|c|c|c|}
\hline \multicolumn{1}{|c|}{ Regression } & Adjusted R & F & Sig. \\
\hline $\begin{array}{l}\text { Relationship commitment in } \\
\text { TSC - collaboration in TSC }\end{array}$ & 0.238 & 10.477 & 0.000 \\
\hline $\begin{array}{l}\text { Trust in TSC- collaboration in } \\
\text { TSC }\end{array}$ & 0.376 & 97.414 & 0.000 \\
\hline $\begin{array}{l}\text { Communication in TSC- } \\
\text { collaboration in TSC }\end{array}$ & 0.374 & 96.618 & 0.000 \\
\hline $\begin{array}{l}\text { Shared values in TSC- } \\
\text { collaboration in TSC }\end{array}$ & 0.400 & 107.817 & 0.000 \\
\hline $\begin{array}{l}\text { Relationship commitment in } \\
\text { TSC- trust in TSC }\end{array}$ & 0.200 & 41.287 & 0.000 \\
\hline $\begin{array}{l}\text { Communication in TSC- trust in } \\
\text { TSC }\end{array}$ & 0.288 & 65.703 & 0.000 \\
\hline $\begin{array}{l}\text { Shared values in TSC- trust in } \\
\text { TSC }\end{array}$ & 0.359 & 90.716 & 0.000 \\
\hline $\begin{array}{l}\text { Communication in TSC- } \\
\text { Relationship commitment in } \\
\text { TSC }\end{array}$ & 0.239 & 51.207 & 0.000 \\
\hline $\begin{array}{l}\text { Shared values in TSC- } \\
\text { Relationship commitment in } \\
\text { TSC }\end{array}$ & 0.289 & 66.015 & 0.000 \\
\hline
\end{tabular}

The results of linear regression from Table 3 show that in first four analysis the collaboration was determined as dependent variable. Four different factors were set at independent variable and the results are following: 
ToSEE - Tourism in Southern and Eastern Europe, Vol. 5, pp. 475-487, 2019

S. Mlaker Kač, E. Mrnjavac, N. Slavić: RELATIONSHIP FACTORS IN TOURISM SUPPLY CHAIN ...

- the results $\left(\Delta \mathrm{R}^{2}=0.238\right.$, sig=0.000) show that relationship commitment in tourism supply chain has a semi strong positive influence on collaboration between partners in tourism supply chain,

- the results $\left(\Delta \mathrm{R}^{2}=0.376\right.$, sig $\left.=0.000\right)$ show that trust in tourism supply chain has a semi strong positive influence on collaboration between partners in tourism supply chain,

- the results $\left(\Delta \mathrm{R}^{2}=0.374\right.$, $\left.\operatorname{sig}=0.000\right)$ show that communication in tourism supply chain has a semi strong positive influence on collaboration between partners in tourism supply chain,

- the results $\left(\Delta \mathrm{R}^{2}=0.400\right.$, sig $\left.=0.000\right)$ show that shared values between partners in tourism supply chain has a semi strong positive influence on collaboration between partners in tourism supply chain.

The results of linear regression from Table 3 also show that in next three analysis the trust was determined as dependent variable. Three different factors were set at independent variable and the results are following:

- the results $\left(\Delta \mathrm{R}^{2}=0.200\right.$, sig $\left.=0.000\right)$ show that relationship commitment in tourism supply chain has a semi strong positive influence on trust between partners in tourism supply chain,

- the results $\left(\Delta \mathrm{R}^{2}=0.288\right.$, sig $\left.=0.000\right)$ show that communication in tourism supply chain has a semi strong positive influence on trust between partners in tourism supply chain,

- the results $\left(\Delta \mathrm{R}^{2}=0.358, \operatorname{sig}=0.000\right)$ show that shared values in tourism supply chain has a semi strong positive influence on trust between partners in tourism supply chain.

The results of linear regression from Table 3 also show that in last two analysis the relationship commitment in tourism supply chain was determined as dependent variable. Two different factors were set at independent variable and the results are following:

- the results $\left(\Delta \mathrm{R}^{2}=0.239\right.$, $\left.\operatorname{sig}=0.000\right)$ show that communication in tourism supply chain has a semi strong positive influence on relationship commitment between partners in tourism supply chain,

- the results $\left(\Delta \mathrm{R}^{2}=0.289\right.$, sig $\left.=0.000\right)$ show that shared values between partners in tourism supply chain has a semi strong positive influence on relationship commitment between partners in tourism supply chain.

\section{DISCUSSION}

Stakeholders in the tourism industry interact with each other to resolve their divergent business objectives with different operating scopes (Song 2012,1). Our research is about that interacting concepts that are needed sustainable, profitable and successful research.

The research results (Figure 2) show that trust between partners in tourism supply chains, commitment that one company in the tourism supply chain has in relationship to others, communication between partners in tourism supply chains and shared values between partners in tourism have direct positive impact on the collaborative behaviour in tourism supply chains in Slovenia and Croatia. 
ToSEE - Tourism in Southern and Eastern Europe, Vol. 5, pp. 475-487, 2019

S. Mlaker Kač, E. Mrnjavac, N. Slavić: RELATIONSHIP FACTORS IN TOURISM SUPPLY CHAIN ...

The research results also show that commitment that one company in the tourism supply chain has in relationship to others, communication between partners in tourism supply chains and shared values between partners in tourism have direct positive impact on the trusting relationships between partners in tourism supply chains in Slovenia and Croatia.

Research also shows that good communication between partners in tourism supply chains and more values that partners share in tourism supply chain have direct positive impact on commitment that one company in the tourism supply chain has in relationship to partners involved in tourism supply chains in Slovenia and Croatia. Therefore relationship commitment in tourism supply chains, shared values between partners in tourism supply chains and communication in tourism supply chains have also indirect impact on successful collaborative behaviour in tourism supply chains.

Figure 2: Research results

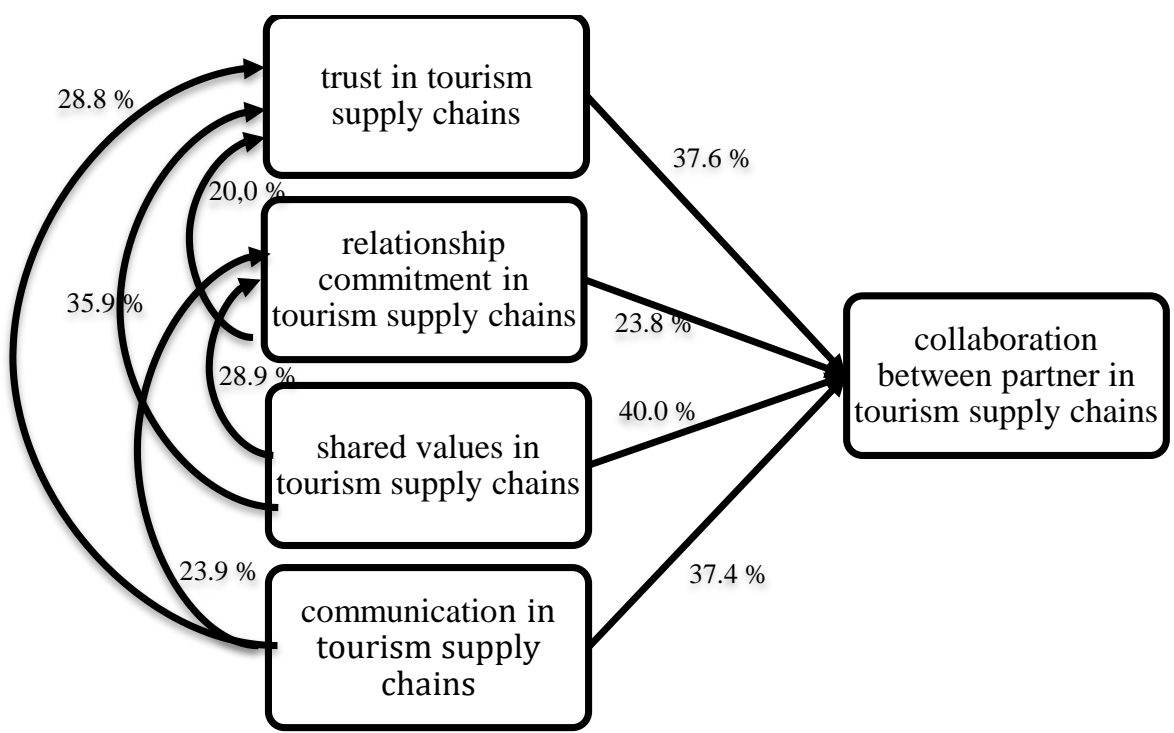

It is important for people working in tourism sector to be aware of the meaning of trust, communication, shared values and relationship commitment and their impact on building long-term relationships. Especially because of the service orientation of the tourism sector it is even more important to have reliable partners (for example for agency it is important to have reliable accommodation partners, for tour operator it is important to have reliable partners in all distribution channels).

Collaboration requires a variety of participants from various echelons of the chain to work together (Zhang, Song and Huang, 2008: 29). And our research shows there are same concepts (like building trust, commitment to partners in supply chain, information sharing and mutual values) that can help companies and managers to start developing long term relationships and let them grow into successful business relationships. 
ToSEE - Tourism in Southern and Eastern Europe, Vol. 5, pp. 475-487, 2019

S. Mlaker Kač, E. Mrnjavac, N. Slavić: RELATIONSHIP FACTORS IN TOURISM SUPPLY CHAIN ...

\section{CONCLUSION}

A tourism product often consists from a variety of service providers, such as accommodation, transport and attraction providers that form tourism supply chain (Song, 2012 , p. 25). Tourism supply chain also often includes travel agencies, tour operators, restaurants etc. in their chain. So, tourism supply chain can be understood as a complex entity of different stakeholders trying to achieve mutual goals.

Tourism supply chain can only be successful when all the partners can interact with each other properly. To achieve that, our research have shown that a high level of trust and relationship commitment is needed for collaborative behavior between partners in tourism supply chains in Slovenia and Croatia. And in addition to that, we have to point out the importance of communication and good information sharing between partners and mutual values that partners in tourism supply chain possess for good business relationships between partners in tourism supply chain. Without before mentioned notions successful and sustainable long term relationships would be hardly achievable.

\section{ACKNOWLEDGEMENTS}

This paper has been financially supported by the University of Rijeka, for the project ZP UNIRI 5/18.

\section{REFERENCES}

Anderson, E. and Weitz, B. (1992), "The Use of Pledges to Build and Sustain Commitment in Distribution Channels", Journal of Marketing Research, Vol. 29, No. 1, pp. 18-34.

Anderson, J.C. and Narus, J.A. (1984), "A model of the distributor's perspective of distributor- manufacturer working relationship", Journal of Marketing, Vol. 48, No. 4, pp. 62-74.

Baldigara, T. and Mamula, M. (2012), "Tourism statistics in Croatia: Present Status and Future Challenges", Procedia-Social and Behavioral Sciences, 44, pp. 53-61.

Castaldo, S. (2007), Trust in market relationships, Edward Elgar, Cheltenham.

Cao, M. and Zhang, Q. (2013), Supply Chain Collaboration: Rules of Interorganizational Systems, Trust and Collaborative Culture, Springer Verlag, London

Chen, J.V., Yen D.C., Rajkumar T.M. and Tomochko N.A. (2011), "The antecedent factors on trust and commitment in supply chain relationships", Computer Standards \& Interfaces, Vol. 33, No. 3, pp. $262-270$.

Christopher, M. (2011), Logistics \& Supply Chain Management, Pearson, Harlow.

Denise, L. (1999), “Collaboration vs. C-Three (Cooperation, Coordination and Communication)”, Innovating, Vol. 7, No. 3, pp. 1-6

Deepen, J.M. (2007), Logistics Outsourcing Relationships: Measurement, Antecedents, and Effects of Logistics Outsourcing Performance, Physica Verlag, Heidelberg.

Gray, B. (1989), Collaborating: Finding Common Ground for Multiparty Problems. Jossey-Bass, San Francisco.

Humphrey, J. (1998), “Trust and the Transformation of Supplier Relations in Indian Industry”. Lane, C. and Bachmann, R. Trust Within and Between Organizations: Conceptual Issues and Empirical Applications, Oxford University Press, Oxford, pp. 214-240.

Kaukal, M., Hopken, W. and Werthner, H. (2000), “An Approach To Enable Interoperability in Electronic Tourism Markets", Proceedings of the $8^{\text {th }}$ European Conference on International System, pp. 1104 1111

Ministry of Tourism Republic of Croatia (2018), Tourism in figures 2017, Ministry of Tourism Republic of Croatia, Zagreb. 
ToSEE - Tourism in Southern and Eastern Europe, Vol. 5, pp. 475-487, 2019

Moorman, C., Zaltman, G- and Deshpande, R. (1992), "Relationship between Providers and Users of Marketing Research: The Dynamics of Trust Within and Between Organizations", Journal of Marketing Research, Aug, 29, pp. 314-328.

Morgan, R.M. and Hunt, S.D. (1994), “The Commitment- Trust Theory of Relationship Marketing”, Journal of Marketing, Vol. 58, No. 3, pp. 20-38

Piboonrungroj, P. (2009), Tourism Supply Chains, viewed 15 February 2019, http://pairach.com/tsc/.

Pollard, D. (2005), Business Innovation, viewed 15 February 2019 , http://howtosavetheworld.ca/2005/03/25/will-that-be-coordination-cooperation-or-collaboration/.

Rangus, M. and Brumen, B. (2016), "Development of Tourism Research", Teorija in praksa, Vol. 53, No. 4, pp. 929-941.

Saab, S. (2007), Commitment in Geschäftsbeziehungen: Konzeptualisierung und Operationalisirung für das Business-to-Business-Markting, Deutsche Universität Verlag, Wiesbaden.

Song, H. (2012), Tourism Supply Chain Management, Routledge, Taylor \& Francis Group, London and New York

STO (2018), Tourism in numbers 2017, Slovenian Tourist Board, Ljubljana.

Svensson, G. (2005), "Mutual and interactive trust in business dyad: condition and process", European Business Review, Vol. 17, No. 5, pp. 411-427.

Tapper, R. and Font, X. (2004), Tourism Supply Chain, Report of a Desk Research Project For The Travel Foundation, Leeds Metropolitan University, Environment Business \& Development Group, Leeds.

Waters, D. (2007), "Trends in the supply chain”, Waters, D. Global Logistics: New Directions in Supply Chain Management, Kogan Page, London, Philadelphia, pp. 1-20.

Wang, J. (2009), "Trust and relationship commitment between direct selling distributors and customers", African Journal of Business Management, Vol. 3, No. 12, pp. 862-870.

World Travel and Tourism Council (2018a), Travel \& Tourism, Economic Impact 2018 Croatia, viewed 19 February 2019, https://www.wttc.org/-/media/files/reports/economic-impact-research/countries2018/croatia2018.pdf

World Travel and Tourism Council (2018b), Travel \& Tourism, Economic Impact 2018 Slovenia, viewed 19 February 2019, https://www.slovenia.info/uploads/dokumenti/raziskave/slovenia2018.pdf

World travel\& tourism council (2019), Direct Contribution to Employment, viewed 17 April 2019 , https://www.wttc.org/datagateway

Zhang, X., Song, H. and Huang G.Q. (2009), "Tourism Supply Chain Management: A New Research Agenda", Tourism Management, Vol. 30, No. 3, pp. 345-358.

Sonja Mlaker Kač, PhD, Assistant Professor

University of Maribor, Faculty of Logistics

Mariborska 7, 3000 Celje, Slovenia

Phone: +386342853325

E-mail: sonja.mlaker@um.si

Edna Mrnjavac, PhD, Full Professor

University or Rijeka, Faculty of Tourism and Hospitality Management

Primorska 42, 51410 Opatija, Croatia

Phone: +385 51294697

E-mail: ednam@fthm.hr

Nataša Slavić, PhD, Assistant Professor

University or Rijeka, Faculty of Tourism and Hospitality Management

Primorska 42, 51410 Opatija, Croatia

Phone: +385 51294697

E-mail: natasa.slavic@ fthm.hr 